\title{
Změna postojů českých žáků k matematice během školní docházky ${ }^{1}$
}

\author{
Martin Chvál \\ Univerzita Karlova v Praze, Pedagogická fakulta
}

\begin{abstract}
Abstrakt: Výsledky mezinárodních výzkumů výsledků vzdělávání nás upozorňují, že naše žáky nebaví matematika. Diferencovanější pohled na vztah našich žáků k matematice nabízí výzkumy Hrabala a Pavelkové. Předložená studie se zaměřuje na to, jak se mění vztah žáků k matematice během školní docházky. Činí tak v úvodu hledáním stop těchto informací ve výsledcích výzkumů PISA a TIMSS a v publikacích jmenované výzkumné dvojice. Vlastní výzkum byl realizován metodou sémantického diferenciálu na vzorku 4351 žáků z 53 škol z 230 tříd počínaje 4. ročníkem základní školy a konče posledním ročníkem školy střední. Data byla shromážděna prostřednictvím elektronického portálu vytvořeného v rámci národního projektu Cesta ke kvalitě. Výsledky jsou prezentovány po jednotlivých ročnících a zvlášt' podle typu střední školy. Zřetelné je postupné zhoršování vztahu žáků k matematice. U českého a cizího jazyka obdobný prokazatelný trend není.
\end{abstract}

Klíčová slova: sémantický diferenciál, postoj žáků k matematice, PISA, TIMSS, Cesta ke kvalitě

\section{Change of attitudes of Czech pupils towards mathematics during school attendance}

Abstract: Results of international research show that Czech pupils don't like mathematics. The relationship of Czech pupils to mathematics has also been studied by Hrabal and Pavelkova who give more differentiated view on it. My study focuses on the change of Czech pupils towards mathematics during school attendance. First I analyzed the results of the mentioned studies. Then I used semantic differential method to measure pupils' attitudes toward mathematics. The sample consisted of 4351 pupils from 53 schools and 230 classes from 4th grade of basic school till the last grade of secondary school. Data were collected electronically as part of the national project Road to Quality Improvement. The results are presented by grades and by the type of secondary school. It is clear that attitudes of Czech pupils towards mathematics worsen during school attendance. This trend is not observable in pupils' attitudes towards Czech language and to foreign language.

Keywords: semantic differential, mathematics attitudes, PISA, TIMSS, Road to Quality Improvement

\section{1 Úvod}

České žáky nebaví matematika. Ukazují to výsledky z mezinárodních výzkumů od roku 1995, „vědí to“ učitelé (Hrabal \& Pavelková, 2010), veřejnost i politici. Jak si jinak vysvětlit to, že matematika je na jedné straně vnímána veřejností jako jeden

1 Text je výstupem řešení projektu GA ČR: Vztahy mezi dovednostmi, vzděláváním a výsledky na trhu práce: longitudinální studie (číslo P402/12/G130). 
50 ze tř́ klíčových předmětů (Walterová et al., 2010) a na straně druhé nebyla a není součástí „státní maturity“, byt' je toto tématem stále se vracejících diskusí?

Možností, jak měřit postoje žáků ke školním předmětům, není mnoho. Z kvantitativních metod, konkrétně metod dotazníkových, se nabízejí v zásadě tři. První a v zahraničí patrně i nejvíce užívaný způsob je pomocí indexů, u nichž je usilováno o vysokou míru vnitřní konzistence položek, které daný index tvoří. Toto je i cesta, která se volí v mezinárodních výzkumech, kdy je potřeba získat pomocí málo (4 až 6 ) položek relativně přesnou informaci o každém dotazovaném žákovi, aby mohla být tato informace dávána i do korelačních souvislostí s dalšími proměnnými, zejména pak s výsledky dosaženými $v$ testech.

Další možností je precizně formulovat několik položek, z nichž každá měří něco trochu jiného, a interpretovat tyto položky samy o sobě. To je cesta dotazníku Hrabala a Pavelkové (2010), kteří vytvořili krátký dotazník, ale primárně pro potřeby autodiagnostiky učitele. Zde tedy nejde o „přesnou“ informaci o každém žákovi, ale o získání informací pro učitele o každém žákovi v několika položkách, aby mohl učitel konfrontovat tyto žákovské výpovědi se svojí vlastní představou o jednotlivých žácích. Tím, kdo interpretuje výsledky o každém žákovi, je tedy vždy učitel. Tato interpretace napomáhá učiteli lépe pochopit jednotlivé žáky, ale zároveň učiteli také napomáhá uvědomit si možné vědomé i nevědomé preference určitých typů žáků.

Třetí možností je metoda sémantického diferenciálu, jak ji vymyslel Charles Osgood se svými spolupracovníky (Osgood, Suci, \& Tannenbaum, 1957). Jedná se o dotazníkovou metodu zaměřenou na subjektivní vnímání pojmů. Tato metoda neposkytuje tak přesné indexy jako metoda první. Dominantní index hodnocení pojmů není tak specificky interpretovatelný jako indexy mezinárodních výzkumů či položky dotazníku Hrabala a Pavelkové, ale nabízí možnost mapovat subjektem ne zcela vědomě kontrolované vzdálenosti pojmů v prostoru jeho hodnotového vnímání.

Žádná z uvedených metod však neměří přesně to, co psychologové teoreticky vymezují jako postoje. $V$ těchto dotazníkových metodách nelze z principu podchytit behaviorální složku postojů, která k nim vedle složky kognitivní a afektivní vždy patří (viz např. Atkinson, 2003; Nakonečný, 1995; Vašt’atková \& Chvál, 2010). Tato redukce pojmu při jeho operacionalizaci je však běžně vědomě přijímána (viz např. Atkinson, 2003, kdy mluví o postojích získaných na základě dotazníkových průzkumů). Někdy se při interpretacích mluví opatrněji spíše o „vztazích k“ než o „postojích k“. $\mathrm{V}$ tomto textu užíváme obě možnosti vzhledem $\mathrm{k}$ uvedeným důvodům. Postoje samotné bývají navíc definovány jako „hodnotící vztahy“ (Nakonečný, 1995, s. 195). Sémantický diferenciál je založen na tom, že respondenti mají mnohem méně pod vědomou kontrolou výsledky dotazníku, a to zejména proto, že způsob statistického zpracování je pro respondenty neznámý a výsledek snadno nepredikovatelný. Tím se mohou výsledky sémantického diferenciálu dostat bliže i k afektivní stránce postojů $\checkmark$ porovnání s předcházejícími dvěma dotazníkovými metodami.

Co víme o našich žácích $z$ výzkumů, které užívají první dvě uvedené varianty, je představeno zde v úvodu textu. Třetí metoda byla užita v empirickém výzkumu, na jehož výsledky je dominantně zaměřena tato studie. 
V mezinárodních srovnávacích výzkumech TIMSS a PISA je vztah žáků k matematice zjišt’ován několika indexy. Některé jsou v obou výzkumech obdobné, jiné ne. Některé jsou během let relativně stabilní, některé nové se objevily až v posledních vlnách těchto výzkumů. Tyto indexy je možné utřídit do tři kategorií podle predikční síly pro výsledky žáků v testu z matematiky. Označme je pracovně Mám rád matematiku, Matematika mi jde, Tuhle úlohu z matematiky zvládnu. Ve výzkumu PISA byla matematika dominantní oblastí v roce 2003 (výsledky z roku 2012 budou známy na podzim roku 2013) a na vztah žáků k matematice byla soustředěna zvýšená pozornost.

Do kategorie indexů Mám rád matematiku spadají indexy:

- PISA INTMAT (Interest in and Enjoyment of Mathematics - zájem o matematiku);

- TIMSS PATM (Positive Affect Toward Mathematics - vztah žáků k matematice);

- PISA INSTMOT (Instrumental Motivation to Learn Mathematics - motivace ke studiu matematiky);

- TIMSS SVM (Students Valuing Mathematics - hodnocení matematiky).

Tyto indexy vysvětlují nejmenší procento variability výsledků v matematickém testu. Toto procento je níže uvedeno v závorce za příslušným indexem. Nejprve je uvedena hodnota za ČR a dále hodnota za zúčastněné země v daném výzkumu. U výzkumu PISA je na mezinárodních datech spočítán průměr z variability jednotlivých zemí, u výzkumu TIMSS je určen medián variability jednotlivých zemí. Ve výzkumu PISA je variabilita uváděna s přesností na 1 desetinné místo, ve výzkumu TIMSS na celočíselné hodnoty: INTMAT (3,9 v ČR / 1,5 průměr OECD2), INSTMOT $(1,0 / 0,7)$, PATM ( 3 v ČR / 3 mezinárodní medián TIMSS - 4. ročník, 2007; 9 / 8 - 8. ročník, 2007), SVM (2 / 4 - 8. ročník, 2007). Korelace mezi indexy INTMAT a INSTMOT je v ČR 0,59; průměr OECD je 0,61; mezi indexy PATM a SVM na souhrnných mezinárodních datech je korelační koeficient 0,66 ve 4. ročníku a 0,72 v 8. ročníku (OECD, 2003; Johansone \& Malak, 2008; Martin \& Preuschof, 2008).

Umístění ČR mezi ostatními zeměmi v tabulkách 1-3 slouží jen jako orientační informace, protože seznam zúčastněných zemí v jednotlivých vlnách výzkumu i v obou výzkumech je odlišný.

Do kategorie indexů Matematika mi jde spadají indexy:

- PISA ANXMAT (Mathematics Anxiety - strach z matematiky);

- SCMAT (Mathematics Self-Concept - sebepojetí v matematice);

- TIMSS SCM (Self-Confidence in Learning Mathematics - sebedůvěra v matematice). Tyto indexy vysvětlují o něco vyšší procento variability výsledků v matematickém testu: ANXMAT (16,8 / 12,7), SCMAT (15,8 / 10,8), SCM (18 / 18 - 4. ročník, 2007; 28 / 21 - 8. ročník, 2007). Korelace mezi indexy PISA je následující ANXMAT - SCMAT $(-0,81 /-0,80)$, a je tedy vidět, že oba indexy do značné míry měří to samé, byt' opačně polarizované.

2 Organisation for Economic Co-operation and Development. OECD je zadavatelem výzkumu PISA. 
52 Tabulka 1 Vlastnosti indexů Mám rád matematiku a umístění žáků ČR

\begin{tabular}{|c|c|c|c|c|}
\hline Index & $\begin{array}{l}\text { Počet } \\
\text { položek }\end{array}$ & Př́klad položek & $\begin{array}{l}\text { Cronbachovo } \\
\text { alfa (ČR / M*) }\end{array}$ & Umístění ČR \\
\hline $\begin{array}{l}\text { INTMAT } \\
\text { (PISA) }\end{array}$ & 4 & $\begin{array}{l}\text { Učím se matematiku, } \\
\text { protože mě to baví. }\end{array}$ & $0,85 / 0,90$ & 34. ze 40 \\
\hline $\begin{array}{l}\text { PATM } \\
\text { (TIMSS) }\end{array}$ & $\begin{array}{l}3 \\
\text { (5 položek od } \\
\text { roku 2007) }\end{array}$ & $\begin{array}{l}\text { Matematiku mám } \\
\text { rád(a). }\end{array}$ & $\begin{array}{l}0,84 / 0,82 \\
\text { (4. r. 2007) } \\
0,84 / 0,81 \\
\text { (8. r. 2007) }\end{array}$ & $\begin{array}{l}\text { poslední místo } \\
\text { (8. r., 1995), } \\
\text { na jednom z posledních míst } \\
\text { (8. r., } 1999 \text { a 2007), mezi } \\
\text { posledními } 7 \text { zeměmi } \\
\text { (4. r., 2007), } \\
\text { podprůměrné (4. r., 2011) }\end{array}$ \\
\hline $\begin{array}{l}\text { INSTMOT } \\
\text { (PISA) }\end{array}$ & 4 & $\begin{array}{l}\text { V matematice se } \\
\text { naučím mnoho věcí, } \\
\text { které mi pomohou } \\
\text { získat dobré } \\
\text { zaměstnání. }\end{array}$ & $0,85 / 0,87$ & 21. ze 40 \\
\hline $\begin{array}{l}\text { SVM } \\
\text { (TIMSS) }\end{array}$ & $\begin{array}{l}4 \\
\text { (6 položek od } \\
\text { roku 2011) }\end{array}$ & $\begin{array}{l}\text { Musím být } \\
\text { v matematice } \\
\text { dobrý(á), abych } \\
\text { získal(a) práci, } \\
\text { kterou chci. }\end{array}$ & $\begin{array}{l}0,66 / 0,70 \\
\text { (zjišt'ován } \\
\text { jen v } \\
\text { 8. ročníku } \\
\text { 2007) }\end{array}$ & $\begin{array}{l}\text { na jednom z posledních míst } \\
\text { (8. r., 2007) }\end{array}$ \\
\hline
\end{tabular}

$M^{*}$ - U výzkumu PISA je zde uveden průměr Cronbachova alfa zemí OECD a u výzkumu TIMSS mezinárodní medián z Cronbachova alfa jednotlivých zúčastněných zemí.

Převzato z Palečková \& Tomášek, 2005; Tomášek, 2008.

Tabulka 2 Vlastnosti indexů Matematika mi jde a umístění žáků ČR

\begin{tabular}{|c|c|c|c|c|}
\hline Index & $\begin{array}{l}\text { Počet } \\
\text { položek }\end{array}$ & Př́klad položek & $\begin{array}{l}\text { Cronbachovo alfa } \\
\text { (ČR / } M^{*} \text { ) }\end{array}$ & Umístění ČR \\
\hline $\begin{array}{l}\text { ANXMAT } \\
\text { (PISA) }\end{array}$ & 5 & $\begin{array}{l}\text { Často se bojím, že pro } \\
\text { mě hodina matematiky } \\
\text { bude obtížná. }\end{array}$ & $0,83 / 0,82$ & 27. ze 40 \\
\hline $\begin{array}{l}\text { SCMAT } \\
\text { (PISA) }\end{array}$ & 5 & $\begin{array}{l}\text { Matematiku se učím } \\
\text { rychle. }\end{array}$ & $0,89 / 0,89$ & 30. ze 40 \\
\hline $\begin{array}{l}\text { SCM } \\
\text { (TIMSS) }\end{array}$ & $\begin{array}{l}4 \\
\text { (7 od roku } \\
2011)\end{array}$ & $\begin{array}{l}\text { Matematika mi většinou } \\
\text { jde. }\end{array}$ & $\begin{array}{l}0,75 / 0,72 \\
\text { (4. r. 2007) } \\
0,85 / 0,73 \\
\text { (8. r. 2007) }\end{array}$ & $\begin{array}{l}\text { průměrné } \\
\text { (4. i } 8 . \text { r. 2007), } \\
\text { mírně podprůměrné } \\
\text { (4. r. 2011) }\end{array}$ \\
\hline
\end{tabular}

$M^{*}$ - U výzkumu PISA je zde uveden průměr Cronbachova alfa zemí OECD a u výzkumu TIMSS mezinárodní medián z Cronbachova alfa jednotlivých zúčastněných zemí.

Do kategorie indexů Tuhle úlohu z matematiky zvládnu spadá index PISA MATHEFF (Mathematics Self-Efficacy - sebevědomí při řešení konkrétních úloh). Tento index má nejtěsnější vztah $\mathrm{k}$ dosaženým testovým výsledkům, vysvětlí 31 \% celkové variability ve výsledku matematického testu u žáků v ČR. Průměr zemí OECD je 22,7%. 
Korelace indexu MATHEFF s předešlými indexy je následující: MATHEFF - SCMAT $(0,61$ / 0,62), MATHEFF - ANXMAT $(-0,57$ / -0,52).

Tabulka 3 Vlastnosti indexů Tuhle úlohu z matematiky zvládnu a umístění žáků ČR

\begin{tabular}{|c|c|c|c|c|}
\hline Index & $\begin{array}{l}\text { Počet } \\
\text { položek }\end{array}$ & Příklad položek & $\begin{array}{l}\text { Cronbachovo alfa } \\
\text { (ČR / průměr OECD) }\end{array}$ & Umístění ČR \\
\hline $\begin{array}{l}\text { MATHEFF } \\
\text { (PISA) }\end{array}$ & 8 & $\begin{array}{l}\text { Dokázal(a) bys s jistotou } \\
\text { vyřešit následující } \\
\text { matematické úlohy? } \\
\text { Vyřeš rovnici typu } \\
3 x+5=17\end{array}$ & $0,80 / 0,82$ & 8. ze 40 \\
\hline
\end{tabular}

Z prezentovaných výsledků v tabulkách 1-3 je patrné, že čím blíže má daný index $\mathrm{k}$ testovým výsledkům, tím se naši žáci umist'ují $v$ př́slušném indexu výše. Zjednodušeně se dá říci, že český žák matematiku nemá rád, už mu však nepřipadá matematika tak obtížná a když vidí konkrétní úlohu, troufne si ji vyřešit. Zdá se, ale to $z$ těchto sporadických výsledků nijak přesvědčivě, že vztah našich žáků $\mathrm{k}$ matematice je ve 4 . ročníku o něco lepší než $v 8$. ročníku.

Podrobnější pohled na vztah našich žáků k matematice nám poskytují dlouhodobé výzkumy Hrabala a Pavelkové (2010, 2012). Vzorek obsahoval 3108 žáků (151 tříd 25 základních škol), přibližně rovnoměrně pokrývajících 6 . až 9. ročník základní školy. Data byla shromážděna v období 2005-2008. Tito výzkumníci sledují postoje žáků ke školním předmětům prostřednictvím šesti uzavřených škálových položek s doplněním informace o známce na posledním vysvědčení (Hrabal \& Pavelková, 2010). Sledována je obliba předmětu, jeho obtížnost, přisuzovaný význam a sebehodnocení žáka z hlediska nadání, motivace a píle v daném předmětu. Autoři shrnují, že matematika je žáky vnímána jako jeden z nejneoblíbenějších a nejobtižň̌jších předmětů, žákovské výkony jsou učiteli prostřednictvím známek i nejhưře hodnoceny. Zároveň je matematika žáky vnímána jako vysoce významný předmět (Pavelková \& Hrabal, 2012). Výsledky výzkumů těchto autorů naznačují, byt' na to nebyla primárně zaměřena výzkumná pozornost, že mezi 6. a 9. ročníkem dochází u žáků ke snižení obliby matematiky, narưstá pocit’ovaná obtižnost tohoto předmětu a žákům klesá sebevědomí ohledně nadání pro matematiku. Zdá se, že v těchto naznačených trendech dochází k nejvýraznější změně mezi 6. a 7. ročníkem základní školy. Autoři $v$ rámci norem $\mathrm{k}$ dotazníku prezentují i výsledky šetření z posledních ročníkủ gymnázií (víceletých i čtyřletých souhrnně). Na vzorku 38 tříd jsou výsledky postoje žáků $\mathrm{k}$ matematice srovnatelné $\mathrm{s}$ výsledky žáků posledních ročníků ZŠ. Končící gymnazisté přisuzují matematice výrazně nižší význam než žáci posledních ročníků Zš. Možná je nižši i obliba a motivace pro matematiku. Slovo „možná“ znamená, že průměrné výsledky se liší v porovnání s žáky posledních ročníků ZŠ o 0,2 stupně pětistupňové škály, přičemž prezentované výsledky jsou zaokrouhleny právě na jedno desetinné místo a statistické testy těchto porovnání nebyly realizovány, protože to nebylo středem výzkumnického zájmu autorů. $U$ významnosti byl pokles o 0,7 stupně škály. 
Výše shrnuté výsledky mezinárodních výzkumů mapují vztah našich žáků k matematice relativně přesně (několik položek tvoří vždy jeden index s dostatečnou vnitřní konzistencí). Měří tento vztah prostřednictvím několika indexů. TIMSS mapuje tento vztah u žáků 4. a 8. ročníků, PISA u 15letých žáků. Česká republika se nezapojuje do všech vln těchto výzkumů. Výsledky těchto výzkumů neumožňují spolehlivé popsání změny vztahu žáků $\mathrm{k}$ matematice během školní docházky, pouze přinášejí určité náznaky v uzlových bodech vzdělávací dráhy žáků. Nespornou předností těchto výsledků, i přes vnímanou metodologickou problematičnost spočívající v možném odlišném vnímání škál v odlišném jazykovém a obecně kulturním prostředí (Voňková, 2012), je porovnání vztahu k matematice u žáků České republiky s žáky z ostatních zemí.

Výzkumná pozornost autorů Hrabala a Pavelkové taktéž nebyla primárně zaměřena na sledování změny vztahu žáků $k$ matematice během školní docházky. Jestliže jsme se pokusili některé výsledky $v$ tomto směru rekonstruovat, je to na základě publikovaných orientačních norem pro vytvořený standardizovaný dotazník postojů žáků ke školním předmětům (Hrabal \& Pavelková, 2010).

Pro plánování vlastního výzkumu jsme byli vedeni následujícími výzkumnými otázkami:

- Zhoršuje se vztah našich žáků k matematice během školní docházky, či naopak?

- Liší se vztah k matematice u žáků gymnázií, středních odborných škol a středních odborných učilišt?

- Liší se vztah k matematice u žáků na druhém stupni základní školy a na nižším stupni víceletých gymnázií?

Z těchto otázek vyplývá dominantně popisný charakter cíle výzkumu, který jsme specifikovali následujícím způsobem: Cílem výzkumu je popsat prostřednictvím kvantitativních dat změnu postoje žáků $\mathrm{k}$ matematice během školní docházky počínaje 4. ročníkem základní školy a konče posledním ročníkem školy střední. Čtvrtý ročník byl zvolen jako spodní hranice $z$ důvodu použitelnosti plánované dotazníkové výzkumné metody sémantického diferenciálu.

\section{Použitá metodologie}

Pro zmapování postojů žáků k matematice byla použita dotazníková metoda sémantického diferenciálu (Osgood, Suci, \& Tannenbaum, 1957), v konkrétní úpravě v národním projektu Cesta ke kvalitě (Pöschl, 2011; Chvál et al., 2012). Tento projekt byl vytvořen pro potřeby vlastního hodnocení škol. Zmíněná úprava se opírá o předešlou verzi vytvořenou a ověřenou $v$ rámci diplomové práce (Pöschl, 2005). $Z$ této předešlé verze jsou niže též prezentována vybraná zjištění pro porovnání s aktuálními zjištěními. Aktuální úprava spočívala v zachování škál (výjimku tvořila změna škály z „nudná-zábavná“ na „nudná-zajímavá“) a záměně některých vybraných pojmů. Všechny škály byly sedmistupňové a kódovány od 1 do 7 . 
Použité škály:

- dimenze hodnocení: neužitečná-užitečná, jednotvárná-pestrá, ošklivá-krásná, nudná-zajímavá;

- dimenze aktivity: pomalá-rychlá, stará-mladá, pasivní-aktivní, tuhá-pružná;

- dimenze potence: slabá-silná, vzdálená-blízká, povrchní-hluboká, úzká-široká;

- dimenze složitosti: jednoduchá-složitá.

Použity byly následující pojmy v tomto pořadí: HRA - BUDOUCNOST - PŘíRODA ČESKÝ JAZYK - KULTURA - LÁSKA - VZDĚLÁVÁNÍ - TECHNIKA - PRAVDA - MATEMATIKA ŽIVOT - ŠKOLA - POČÍTAČE - POVINNOST - JÁ - CIZÍ JAZYK - VĚDA - SVĚT.

Oproti původní verzi byly přidány pojmy, které odpovídaly klíčovým školním předmětům: český jazyk, cizí jazyk, počítače a dále pojem vzdělávání. V původní verzi byly navíc fyzika, internet, vzorec, experiment a teorie. Tato úprava odpovídá tomu, že původní verze byla primárně zaměřena na mapování postojů žáků k fyzice. Aktuální verze je potom obecnější nabídkou všem školám pro mapování postojů žáků ke škole a vzdělávání. Pojem matematika i škola je $v$ obou verzích a na přibližně stejném místě dotazníku v uspořádání pojmů.

\subsection{Sběr dat}

Administrace dotazníku byla realizována elektronicky. V rámci projektu Cesta ke kvalitě 3 byl dotazník nabídnut školám pro potřeby vlastního hodnocení s automatickým generováním výsledků. Zahájení administrace bylo v květnu 2010. Sběr dat pro níže prezentované analýzy byl ukončen v únoru 2013. Za toto období dotazník vyplnilo 4350 žáků z 53 škol z 230 tříd, přičemž do 12. 6. 2012 byl v provozu původní portál projektu a zajistil sběr dat od 4108 žáků. Zbývající počet byl shromážděn na nově funkčním portále pod rvp.cz počínaje datem 8. 6. 2012. Účast škol na sběru dat byla dobrovolná, dotazník byl vyplněn na těch školách, které samy projevily zájem získat z něho výsledky pro své vlastní potřeby. Vzhledem $\mathrm{k}$ tomu, že $v$ některých výzkumech bývají identifikovány rozdíly $\vee$ postojích ke školním předmětům mezi chlapci a dívkami a že poměry chlapců a dívek se mohou na různých sledovaných typech škol lišit, je proměnná pohlaví v této studii částečně kontrolována.

Tabulka 4 Přehled struktury vzorku z hlediska typu a ročníku školy

\begin{tabular}{cccccccc}
\hline Typ školy & Ročník & Počet tř́d & Počet žáků & Počet škol & Počet tříd & Počet žáků & $\begin{array}{c}\text { Z toho } \\
\text { děvčat }\end{array}$ \\
\hline & 4. & 3 & $48^{*}$ & & & & \\
ZŠ & 5. & 7 & 133 & & & & \\
& 6. & 33 & 587 & 28 & 128 & 2625 & $48 \%$ \\
& 7. & 18 & 324 & & & & \\
& 8. & 40 & 1055 & & & & \\
\hline
\end{tabular}

3 Dostupné z www.nuv.cz/ae. 


\begin{tabular}{|c|c|c|c|c|c|c|c|}
\hline Typ školy & Ročník & Počet tříd & Počet žáků & Počet škol & Počet tříd & Počet žáků & $\begin{array}{l}Z \text { toho } \\
\text { děvčat }\end{array}$ \\
\hline \multirow{4}{*}{ Nižší G } & 1. & & & \multirow{4}{*}{2} & \multirow{4}{*}{5} & \multirow{4}{*}{$101^{* *}$} & \multirow{4}{*}{$57 \%$} \\
\hline & 2. & 2 & 47 & & & & \\
\hline & 3. & 3 & 54 & & & & \\
\hline & 4. & & & & & & \\
\hline \multirow{4}{*}{ Vyšší G } & 1. & 1 & 20 & \multirow{4}{*}{3} & \multirow{4}{*}{6} & \multirow{4}{*}{$102^{* *}$} & \multirow{4}{*}{$53 \%$} \\
\hline & 2. & 1 & 8 & & & & \\
\hline & 3. & 2 & 36 & & & & \\
\hline & 4. & 2 & 38 & & & & \\
\hline \multirow{4}{*}{ SOŠ } & 1. & 14 & 159 & \multirow{4}{*}{13} & \multirow{4}{*}{65} & \multirow{4}{*}{1167} & \multirow{4}{*}{$46 \%$} \\
\hline & 2. & 18 & 354 & & & & \\
\hline & 3. & 22 & 425 & & & & \\
\hline & 4. & 11 & 228 & & & & \\
\hline \multirow{4}{*}{ SOU } & 1. & 6 & 102 & \multirow{4}{*}{7} & \multirow{4}{*}{26} & \multirow{4}{*}{356} & \multirow{4}{*}{$27 \%$} \\
\hline & 2. & 10 & 147 & & & & \\
\hline & 3. & 10 & 107 & & & & \\
\hline & 4. & & & & & & \\
\hline
\end{tabular}

Pozn.: * I když budou níže prezentovány výsledky za tento ročník, je potřeba je brát s ohledem na nižší počet respondentů a tříd pouze orientačně.

** Pro nižší počty respondentů a tříd budou výsledky za nižší a vyšší stupeň gymnázia prezentovány souhrnně, nikoliv po ročnících. $V$ prípadě jednotného grafického prezentování výsledků po ročnících pak bude zastoupeným ročníkům přiřazena společná průměrná hodnota daného stupně gymnázia.

\subsection{Statistická analýza}

Sémantický diferenciál umožňuje několik rovin prezentace výsledků (viz např. Osgood, Suci, \& Tannenbaum, 1957; Kerlinger, 1972; Chráska, 2007), soustředíme se $v$ této studii primárně na dimenzi hodnocení, která má v porovnání s ostatními dimenzemi nejsilnější interpretační význam vzhledem $\mathrm{k}$ její vyšší vnitřní konzistenci a zejména výrazné dominanci odpovídajícího faktoru ve faktorové analýze (Vašt’atková \& Chvál, 2010). Ačkoliv je matematika ústředním pojmem našeho zkoumání, jsou podobně zpracovány výsledky i pro pojmy český jazyk, cizí jazyk, škola a vzdělání. Učinili jsme tak proto, aby mohl být vztah žáků $k$ matematice upřesněn porovnáním s vnímáním relevantních pojmů - dalších kličových školních předmětů a obecnějších zastřešujících pojmů.

S ohledem na popisný charakter výzkumu jsou výsledky prezentovány graficky se znázorněním průměrných hodnot $v$ dimenzi hodnocení. Na počátku jsou uvedeny vlastnosti této dimenze a statistické charakteristiky škál, které tuto dimenzi tvoří.

Dále byly spočítány matice vzdáleností pojmů v sémantickém prostoru se zvýrazněním některých nejvíce relevantních pojmů pro naše zkoumání. Užit byl standardní postup (viz např. Kerlinger, 1972) pro sémantický diferenciál, tj. vzdálenosti 
mezi dvěma pojmy byly spočíány jako euklidovské vzdálenosti (umístění vzdáleností v $n$-dimenzionálním prostoru, kde $n$ je počet použitých škál v rámci celého sémantického diferenciálu, $v$ našem prípadě tedy $n=13$ ). Souřadnice pojmů jsou spočítány jako průměr hodnot v dané škále vždy pro daný vzorek respondentů.

Veškeré analýzy jsou provedeny zvlášt' po jednotlivých ročnících a typech škol. Tam, kde to přiliš nízké četnosti nedovolují (víceletá gymnázia), jsme za výsledky jednotlivých ročníků dosadili výsledky několika sloučených ročníků. Na tyto okolnosti je při prezentaci příslušných výsledků explicitně upozorněno. Data nejsou nikterak vážena. Orientačně (protože se nejedná o náhodné vzorky žáků z populace) jsou spočítány i dvouvýběrové $t$-testy, vždy pro dva po sobě jdoucí ročníky školy. Výsledky těchto testů jsou v grafech zvýrazněny. Do výsledků těchto testů se samozřejmě výrazně promítají i četnosti vzorků v jednotlivých ročnících - 8. ročník s více než 1000 respondenty se skoro vždy statisticky významně liší od ročníků okolních, byt' ne vždy jsou rozdíly věcně velké, ale stojí za pozornost při sledování celkových trendů. $V$ príloze jsou uvedeny podrobnější statistické výsledky $v$ dimenzi hodnocení po jednotlivých ročnících. Tyto výsledky umožní případným zájemcům realizovat vlastní orientační testy hypotéz pro porovnávání různých skupin či pro porovnávání postojů k vybraným pojmům. Ačkoliv jsou zde uvedeny směrodatné odchylky a standardní chyby odhadu průměru jen pro matematiku, v hrubém přiblížení, které odpovídá charakteru dat, je možné pracovat s odhady směrodatných odchylek v tabulce 5 .

Pro porovnání jsou níže uvedeny i vybrané výsledky výzkumu Pöschla (2005) z pražských čtyřletých gymnázií. Tento výzkum z roku 2004 zahrnoval 901 žáků (37 tříd ze 13 gymnázií), s přibližně polovičním zastoupením čtyřletých a osmiletých gymnázií. Zkoumány byly postoje u žáků na úrovni prvního, druhého a třetího ročníku čtyřletého gymnázia. V aktuálně prezentovaném výzkumu i výzkumu Pöschla byly použity srovnatelné výzkumné metody, jejichž drobné rozdíly jsou popsány výše.

\section{Výsledky}

\subsection{Dimenze hodnocení - vlastnosti}

V této kapitole prezentujeme konstrukční vlastnosti dimenze hodnocení. Výsledky jsou spočítány na celém datovém souboru souhrnně. Vlastnosti dimenze pro sledované pojmy přináší tabulka 5. Vlastnosti škál, které tvoří tuto dimenzi, přináší tabulka 6.

Z tabulky 6 je patrné, že z nabídnutých škál hodnocení daných „školních“ pojmů žáci výrazně více vyzdvihují užitečnost, a to nejvíce u pojmu vzdělání následovaného cizím jazykem. Cizí jazyk však má vyšší hodnocení než vzdělání z hlediska krásy a zajímavosti. Na opačném pólu je škola s podobným profilem jako matematika. Český jazyk je pozitivněji hodnocen v porovnání se školou i matematikou z hlediska krásy. 
Tabulka 5 Vlastnosti dimenze hodnocení

\begin{tabular}{lcccc}
\hline & $\begin{array}{c}\text { Aritmetický } \\
\text { průměr }\end{array}$ & $\begin{array}{c}\text { Směrodatná } \\
\text { odchylka }\end{array}$ & $\begin{array}{c}\text { Standardní chyba } \\
\text { průměru }\end{array}$ & $\begin{array}{c}\text { Cronbachovo } \\
\text { alfa }\end{array}$ \\
\hline Matematika & 4,42 & 1,48 & 0,02 & 0,723 \\
Český jazyk & 4,51 & 1,46 & 0,02 & 0,717 \\
Cizí jazyk & 4,97 & 1,28 & 0,02 & 0,673 \\
Škola & 4,38 & 1,35 & 0,02 & 0,658 \\
Vzdělání & 4,93 & 1,21 & 0,02 & 0,603 \\
\hline
\end{tabular}

Tabulka 6 Vlastnosti škál, které tvoří dimenzi hodnocení

\begin{tabular}{|c|c|c|c|c|c|}
\hline & & $\begin{array}{c}\text { užitečná- } \\
\text { neužitečná }\end{array}$ & $\begin{array}{c}\text { jednotvárná- } \\
\text { pestrá }\end{array}$ & $\begin{array}{l}\text { krásná- } \\
\text { ošklivá }\end{array}$ & $\begin{array}{c}\text { nudná- } \\
\text { zajímavá }\end{array}$ \\
\hline \multirow{3}{*}{ Matematika } & a.p. & 5,42 & 4,26 & 3,95 & 4,04 \\
\hline & s.o. & 1,93 & 2,05 & 1,90 & 2,05 \\
\hline & C.a.- & 0,684 & 0,710 & 0,641 & 0,604 \\
\hline \multirow{3}{*}{ Český jazyk } & a.p. & 5,38 & 4,38 & 4,32 & 3,95 \\
\hline & s.o. & 1,92 & 2,03 & 1,90 & 2,00 \\
\hline & C.a.- & 0,673 & 0,712 & 0,620 & 0,607 \\
\hline \multirow{3}{*}{ Cizí jazyk } & a.p. & 5,89 & 4,60 & 4,75 & 4,59 \\
\hline & s.o. & 1,66 & 1,90 & 1,72 & 1,85 \\
\hline & C.a.- & 0,641 & 0,633 & 0,600 & 0,547 \\
\hline \multirow{3}{*}{ Škola } & a.p. & 5,54 & 4,14 & 3,87 & 3,96 \\
\hline & s.o. & 1,90 & 1,97 & 1,76 & 1,94 \\
\hline & C.a.- & 0,629 & 0,608 & 0,592 & 0,527 \\
\hline \multirow{3}{*}{ Vzdělání } & a.p. & 6,24 & 4,57 & 4,51 & 4,38 \\
\hline & s.o. & 1,43 & 2,00 & 1,68 & 1,91 \\
\hline & C.a.- & 0,584 & 0,541 & 0,538 & 0,449 \\
\hline
\end{tabular}

Pozn.: a.p. je aritmetický průměr; s.o. je směrodatná odchylka; C.a.- je Cronbachovo alfa dimenze hodnocení $v$ prípadě vynechání dané škály, jedná se o ukazatel citlivosti položky $v$ rámci dimenze hodnocení. Všechny škály jsou již natočeny tak, že vyšší hodnota znamená pozitivnější hodnocení.

Jako nejsilnější škála v dimenzi hodnocení (viz nejnižší hodnoty proměnné C.a.-) se ukazuje nudná-zajímavá. Její přínos pro vnitřní konzistenci dimenze hodnocení je nejvy̌ší, a to u všech posuzovaných pojmů. Naopak méně přínosné jsou škály užitečná-neužitečná a jednotvárná-pestrá.

Variabilita názorů na matematiku je srovnatelná s českým jazykem a školou. Názory na cizí jazyk a vzdělání jsou homogennější (viz nižší hodnoty směrodatných odchylek).

Při porovnání postojů k matematice, ve faktoru hodnocení, nebyly mezi chlapci a dívkami u matematiky zaznamenány statisticky významné rozdíly $v$ jednotlivých 
typech škol ( $p$ > 0,05). Výjimku tvořily nižší stupně víceletých gymnázií, kde matematika byla pozitivněji hodnocena dívkami $(p=0,008)$. Vzhledem $k$ nízkému počtu respondentů a nenáhodnému výběru žáků však tomuto výsledku nebude nadále věnována pozornost. Jestliže u matematiky rozdíly mezi chlapci a dívkami nebyly zaznamenány, tak u českého jazyka i cizího jazyka platí, že je v každém typu školy děvčata vnímají pozitivněji než chlapci $(p<0,001)$. Výjimku tvoří hodnocení cizího jazyka na vyšším stupni gymnázia $(p=0,108)$, ale podobně pro nízký počet respondentů a nenáhodný výběr žáků nebude tomuto výsledku dále věnována pozornost.

\subsection{Porovnání výsledků podle ročníků - dimenze hodnocení}

Následující grafy ukazují průměrné výsledky v dimenzi hodnocení pro jednotlivé pojmy po jednotlivých ročnících. Hodnota za 4. ročník je graficky odlišena „prázdným kolečkem"s upozorněním, že výsledek je jen orientační s ohledem na nižší velikost vzorku žáků 4. ročníku. Hodnoty za víceletá gymnázia jsou prezentovány jen prostřednictvím dvou průměrů - za nižší stupeň průměrem odpovídajícím 7. a 8. ročníku ZŠ, za vyšší stupeň průměrem všech čtyř ročníků střední školy. V grafech jsou tyto průměrné výsledky přiřazeny všem odpovídajícím ročníkům, ze kterých byl tento průměr spočítán. Samožrejmě spojnice mezi body grafu nemají význam a slouží jen jako orientační vodítka mezi body za př́slušný typ školy. Tam, kde jsou rozdíly mezi ročníky statisticky významné (při zvolené hl. význ. 0,05), je spojnice mezi těmito ročníky zvýrazněna tučně. Pro přesnější pohled na data grafů viz příloha Tabulka 11.

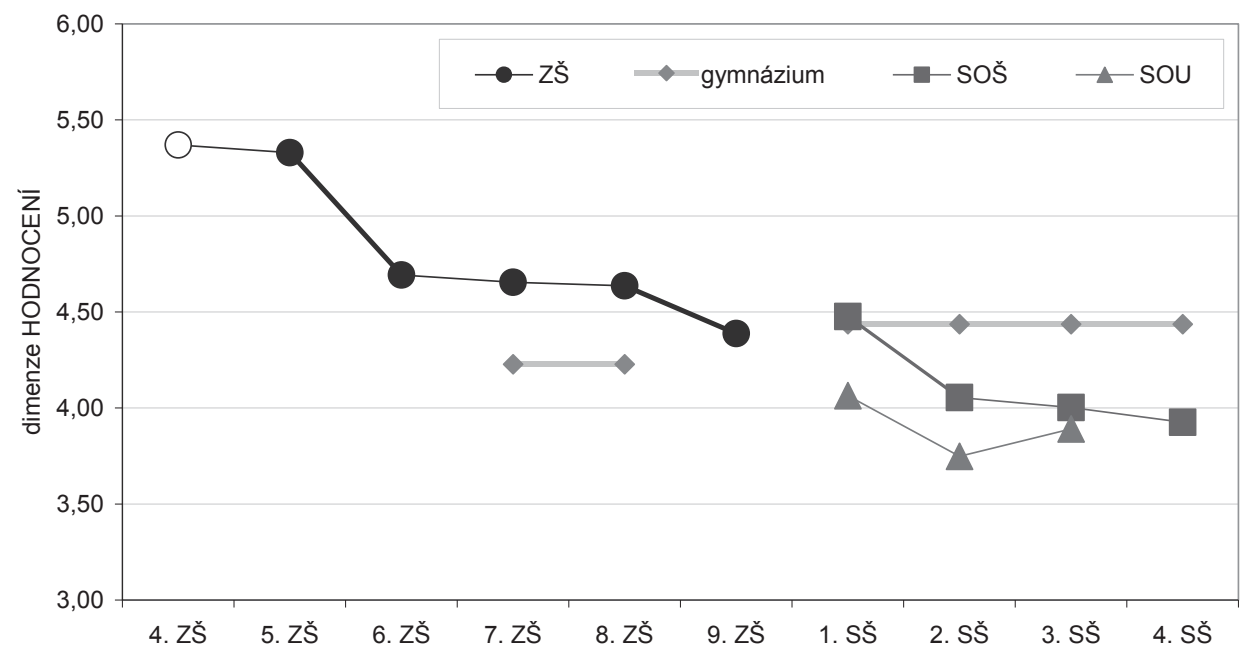

Graf 1 Změny postoje žáků: MATEMATIKA

Výsledky výzkumu Pöschla (2005) jsou srovnatelné s těmito. Toto porovnání činíme i s ohledem na to, že škála nudná-zábavná byla oproti Pöschlově výzkumu nahrazena škálou nudná-zajímavá. Průměr dimenze hodnocení matematiky byl u žáků 
60 pražských gymnázií 4,26. Mírné, ale zanedbatelné (statisticky nevýznamné) rozdíly byly mezi žáky čtyřletého a osmiletého gymnázia: 4,34 vs. 4,23. Prokazatelnější trendy ve vývoji mezi prvním až třetím ročníkem nebyly zaznamenány.

Z grafu 1 zřetelně vyplývá postupně se zhoršující vztah žáků k matematice s výraznějším zlomem mezi pátým a šestým ročníkem. Toto zhoršování pokračuje i na střední škole. Za gymnázia nemáme $v$ tomto ohledu spolehlivé údaje, za střední odborná učiliště výsledky mluví nejednoznačně. Pokud jde o žáky středních odborných škol, za které jsou i vyšší četnosti respondentů, tak je tento pokračující trend patrný. Současně vidíme, že samotným přechodem žáků mezi 9. ročníkem a střední školou se tento vztah př́liš nemění (pouze odděluje žáky s nižším hodnocením matematiky do středních odborných učilišt').

Vzhledem k množství dat a charakteru vzorku nelze přeceňovat výsledky, ale minimálně za poukázání stojí skutečnost, že $v$ našem výzkumu mají žáci z nižších stupňů gymnázií horší vztah k matematice než žáci na druhém stupni základních škol.

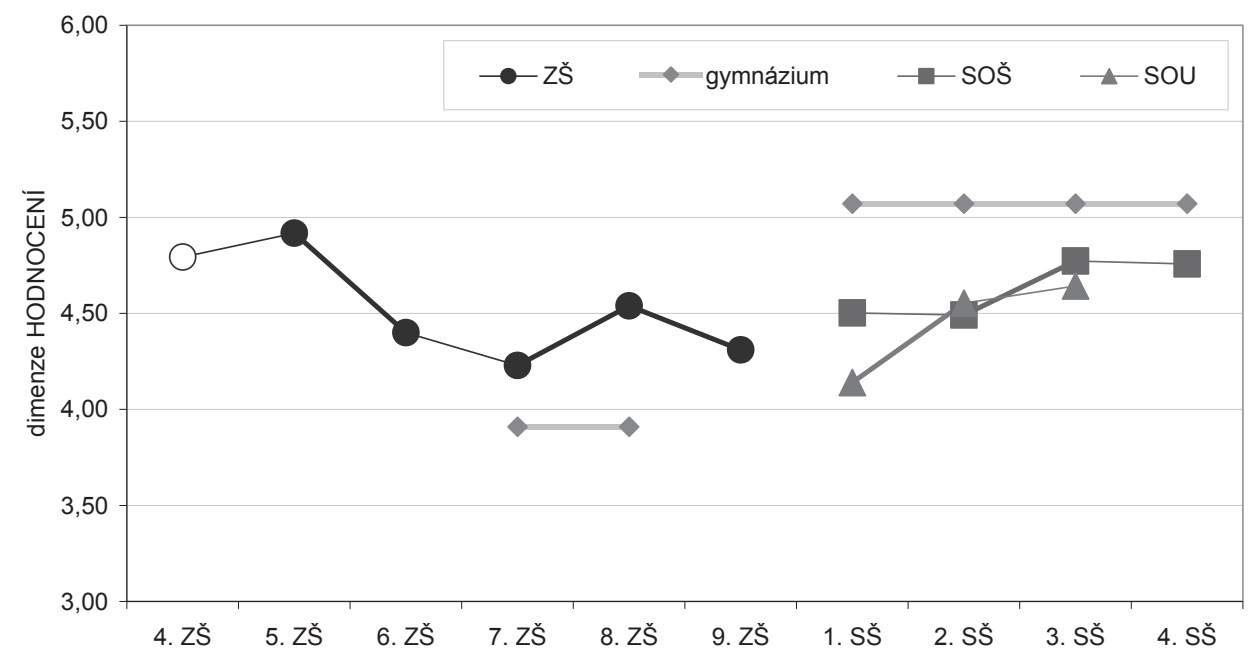

Graf 2 Změny postoje žáků: ČESKÝ JAZYK

Změna postoje žáků k českému jazyku a cizímu jazyku je zcela odlišná od matematiky. U českého jazyka dochází rovněž ke zhoršení vztahu mezi pátým a šestým ročníkem, ale dále tento trend nepokračuje. Ba naopak, na střední škole, a zřetelněji na středních odborných učilištích, začíná být český jazyk vnímán pozitivněji ve vyšších ročnících než v nižších, a to dokonce pozitivněji než ke konci základní školy. Patrné je pozitivnější vnímání českého jazyka na vyšším stupni gymnázia. Nejvíce negativně vnímají v našem výzkumu český jazyk žáci nižšího stupně gymnázia.

Vnímání cizího jazyka je výrazně diferencováno podle typu střední školy. Nepřekvapí, že nejpozitivněji je vnímán žáky gymnázií, potom středních odborných škol a nejméně pozitivně žáky středních odborných učilišt'. Cizí jazyk si v zásadě drží stabilní a z porovnávaných předmětů nejpozitivnější vnímání žáky při průchodu 
školní docházkou. Za povšimnutí též stojí, že oproti matematice a českému jazyku vnímají žáci nižších stupňủ gymnázií cizí jazyk pozitivněji než jejich vrstevníci, kteří zůstali na základních školách.

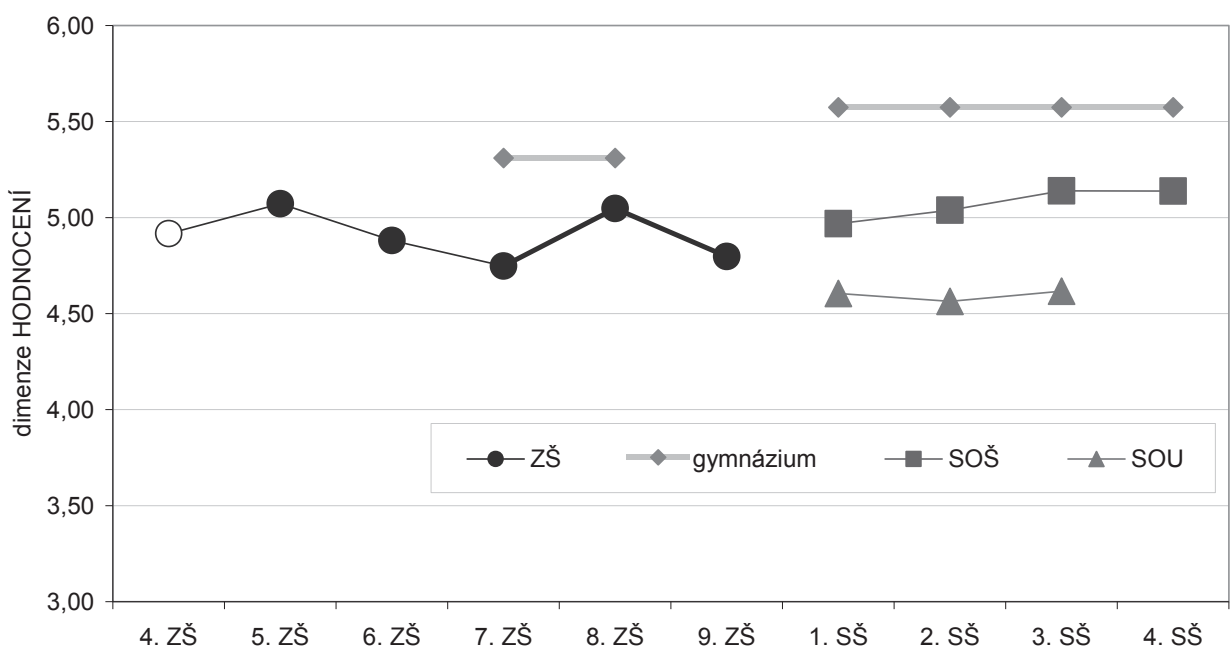

Graf 3 Změny postoje žáků: CIZÍ JAZYK

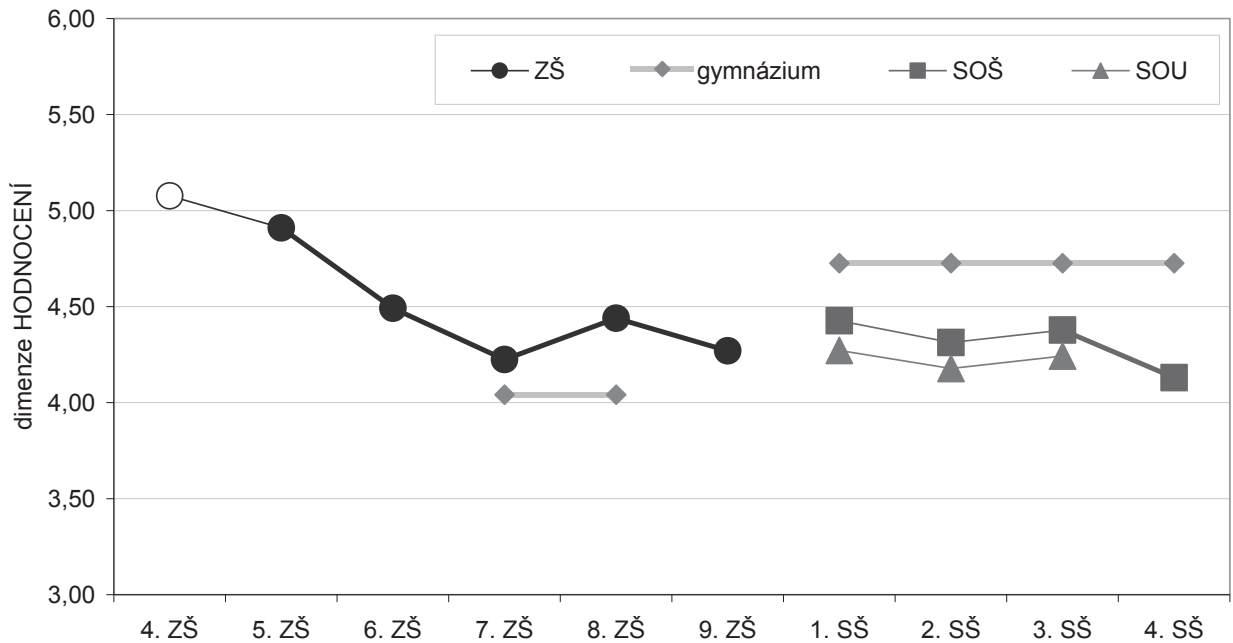

Graf 4 Změny postoje žáků: ŠKOLA

Podobně jako u matematiky, také u vztahu žáků ke škole přinášejí Pöschlovy výzkumy srovnatelné výsledky. Škola je vnímána žáky pražských gymnázií podobně jako matematika s průměrem $4,24 \mathrm{v}$ dimenzi hodnocení. Na rozdíl od matematiky jsou výraznější a statisticky významné rozdíly $(p<0,01)$ mezi žáky čtyřletých a osmiletých gymnázií: 4,41 vs. 4,06 . 
62 Z grafu vyplývá, že žáci na nižším stupni gymnázia vnímají školu výrazně negativněji než na vyšším, a to i v porovnání s vrstevníky na druhém stupni základní školy (potvrzeno také statistickými testy na hladině významnosti 0,05 ).

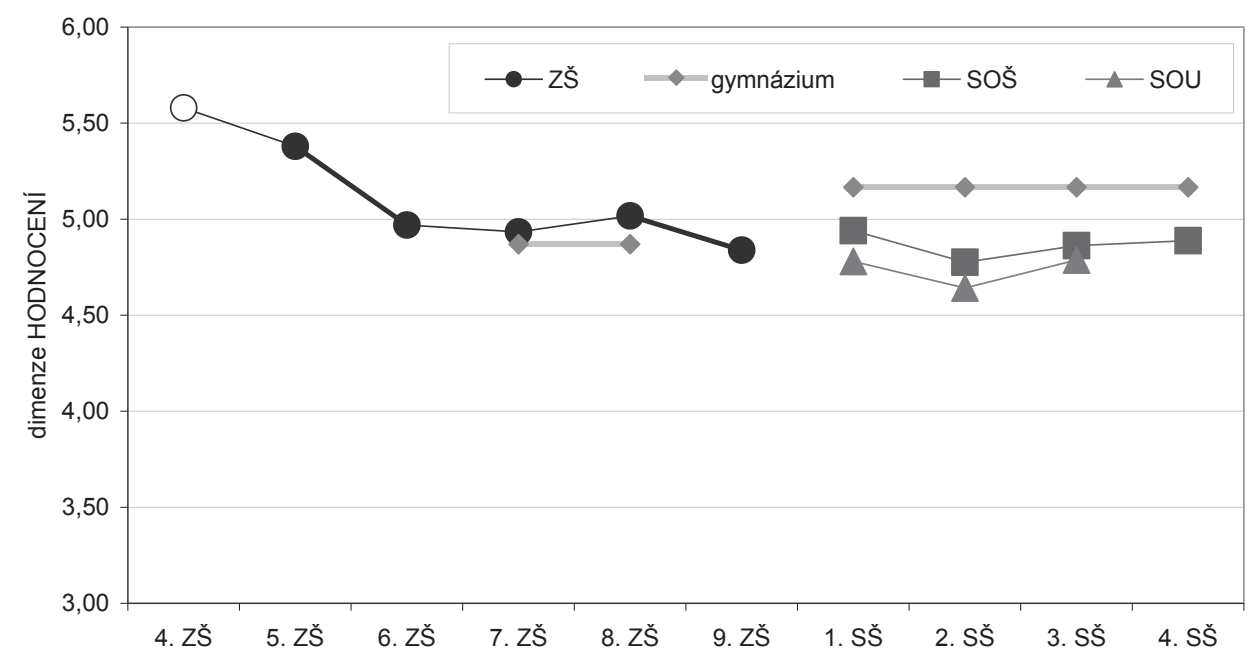

Graf 5 Změny postoje žáků: VZDĚLÁNÍ

Vnímání pojmu vzdělání je v porovnání s ostatními pojmy relativně stabilní během školní docházky počínaje 6 . ročníkem základní školy a konče posledním ročníkem školy střední.

\subsection{Porovnání výsledků podle ročníků - matice vzdáleností pojmů}

Zde jsou prezentovány vzdálenosti pojmů v sémantickém prostoru prostřednictvím matic. Uvádíme dva typy matic. První (tabulka 7) ukazuje vzdálenost každého pojmu s každým pojmem pro celý soubor žáků. Další tři matice (tabulky $8,9,10$ ) potom zobrazují jen vzdálenost pojmů matematika, český jazyk a cizí jazyk ke všem ostatním pojmům, ale zvlášt' podle jednotlivých ročníků základních a středních škol. Jen výsledky za nižší a vyšší ročník gymnázia jsou prezentovány souhrnně, nikoliv po ročnících, $z$ výše uvedeného důvodu menší velikosti vzorků. Vedle ústředních sledovaných pojmů jsou v tabulkách zvýrazněny pojmy, které pokládáme ve vztahu k sledovaným pojmům za nejvíce relevantní: já, budoucnost, život, svět, pravda, kultura. $\mathrm{K}$ těmto pojmům je potom zaměřena i interpretační pozornost.

Matematiku mají žáci silně asociovanou se školou a povinností, podobně blízko nich stojí i český jazyk. Vzdálenost pojmu cizí jazyk od pojmu škola je již o něco větší. Jestliže matematika a český jazyk si vzhledem k ostatním pojmům stojí obdobně, cizí jazyk žáci vnímají jinak. Mají ho více asociován s budoucností, životem, světem a vzděláním. 


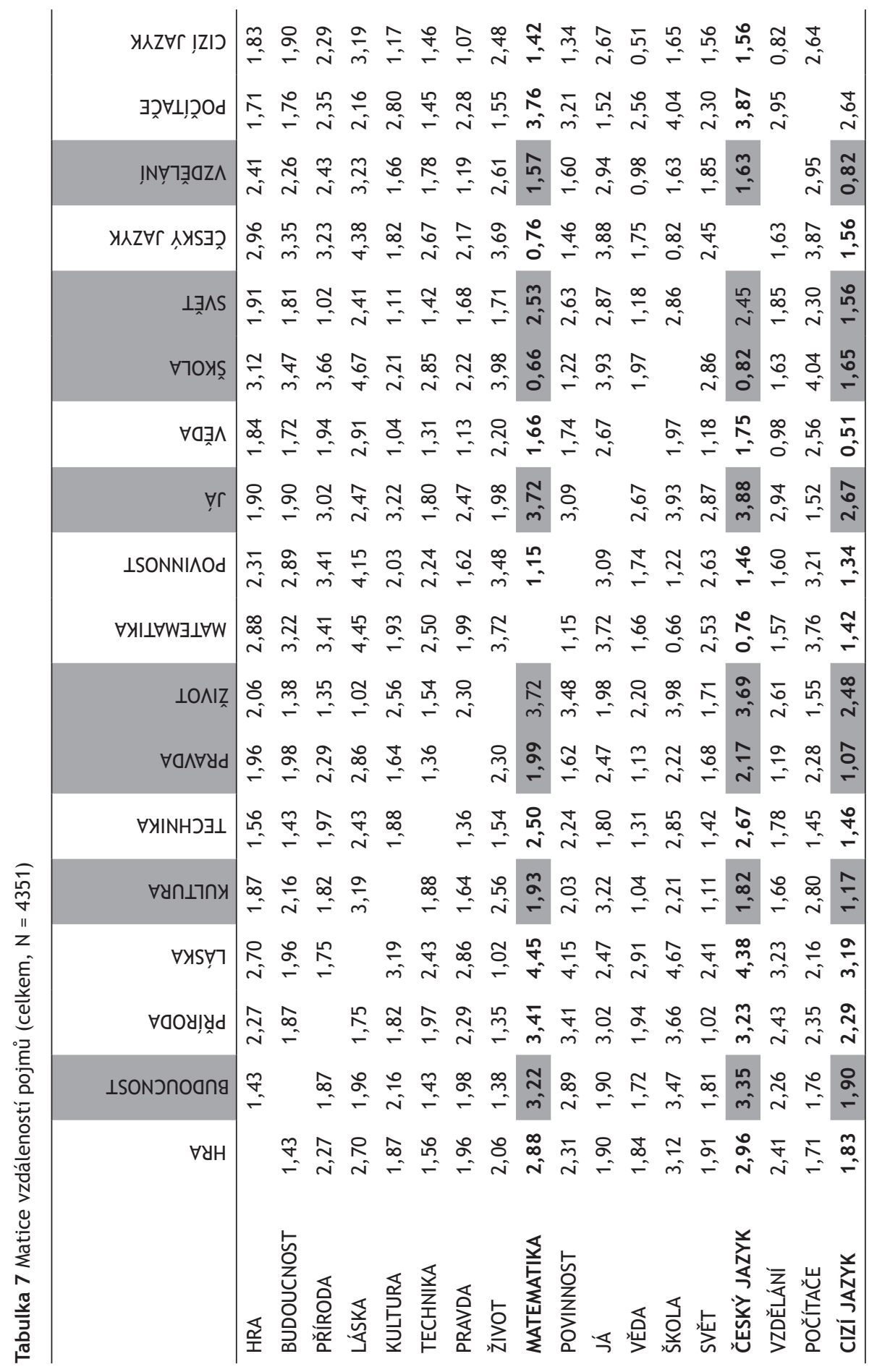




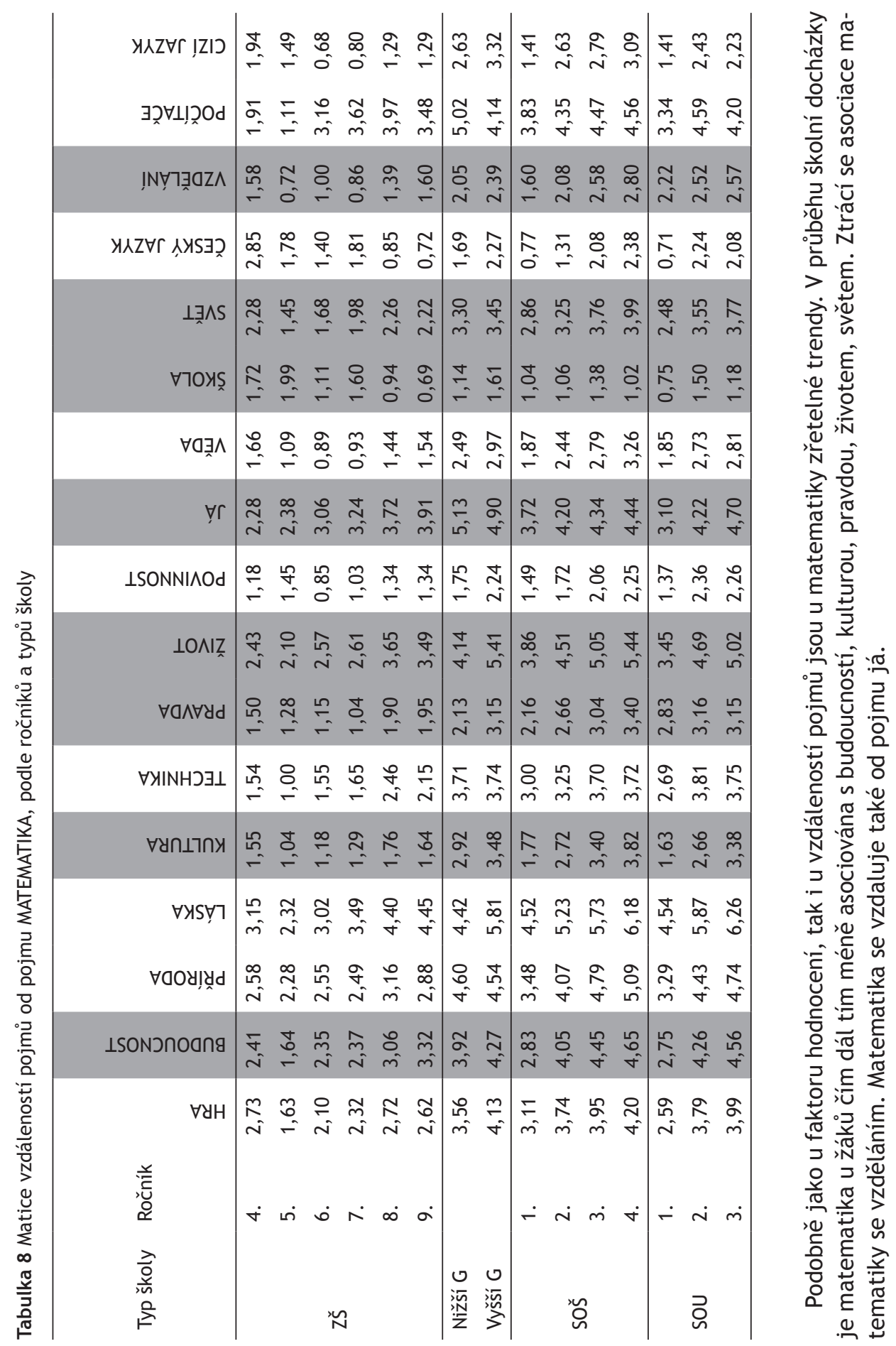




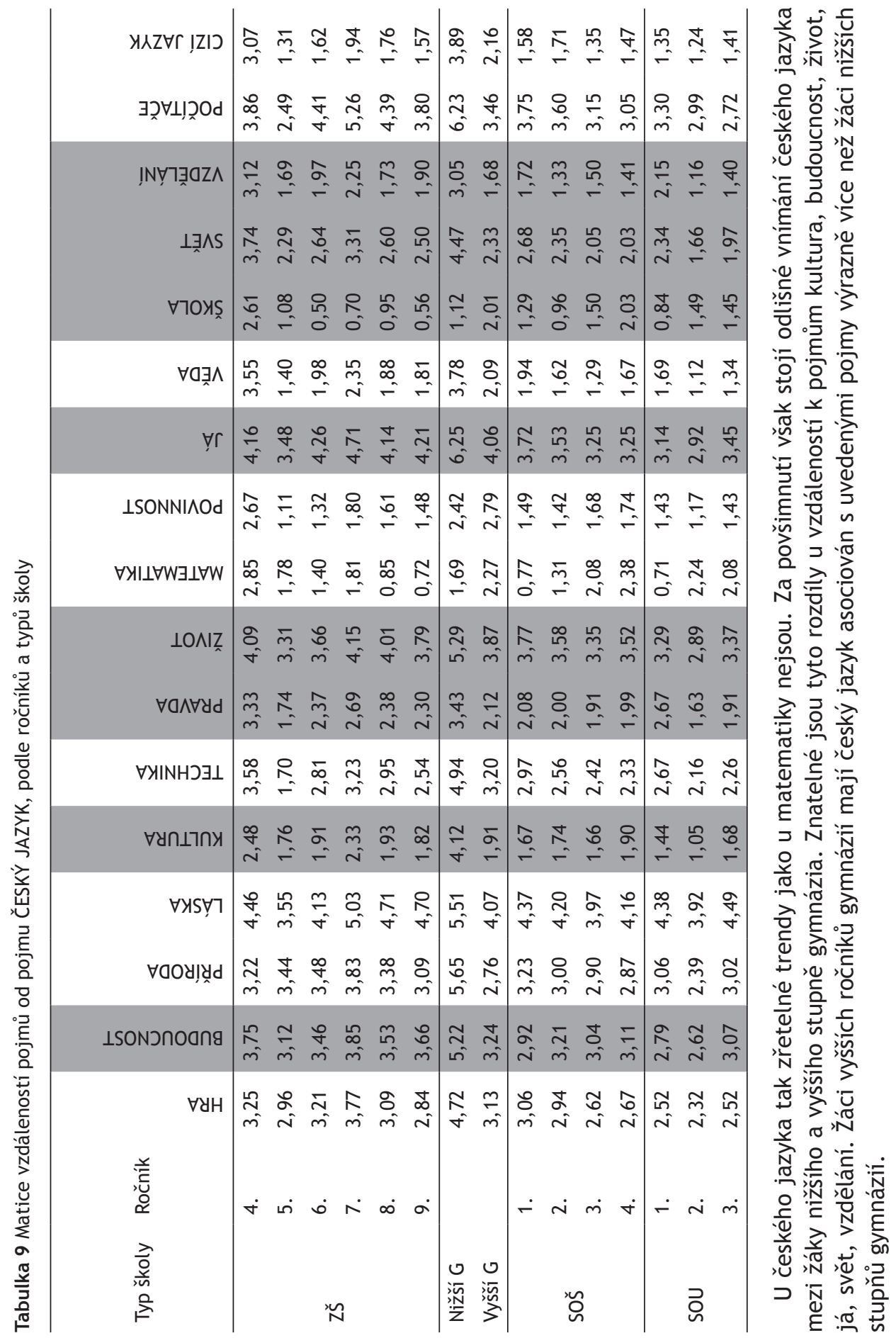


66

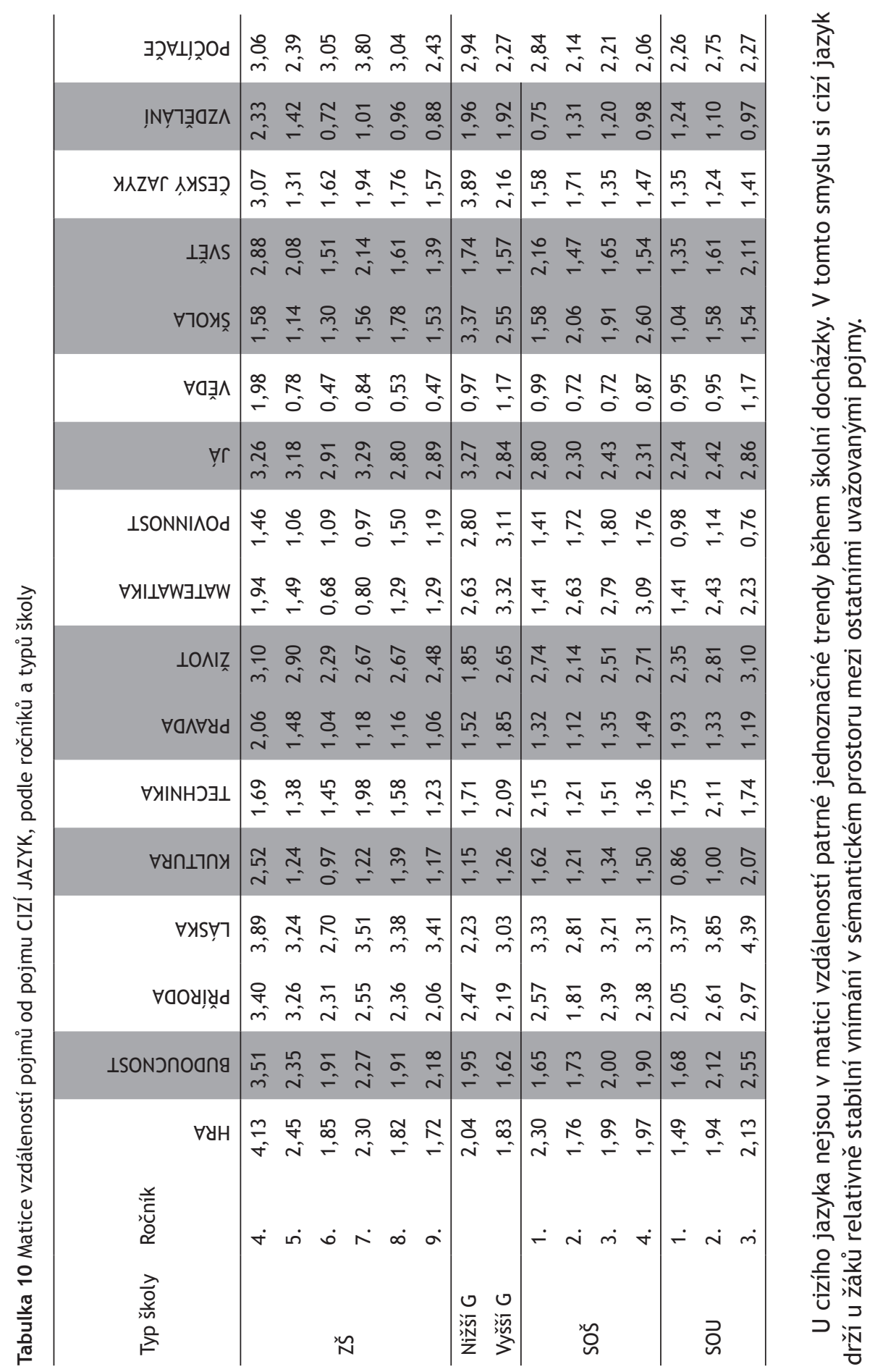




\subsection{Stabilita výsledků}

Ačkoliv součástí zde prezentovaného výzkumu nebylo ověřování časové stability výsledků z použitého dotazníku sémantického diferenciálu, lze na vysokou stabilitu výsledků poukázat z výzkumu Pöschla (2007). Ten použil dotazník, na který jsme se výše odkazovali, v mírně obměněné podobě (jen s doplněním pojmu biologie) znovu v roce 2007 a opět u žáků pražských gymnázií. Soustředil se jen na třetí ročníky. Z komparace výsledků shodných ročníků z původních dat z roku 2004 (276 žáků) a dat nových (230 žáků) v jednotlivých škálách i z umístění pojmů v sémantickém prostoru vyplývá vysoká časová stabilita výsledků v dané skupině respondentů. S př́ijatelnou mírou zobecnění Pöschlem ověrené časové stability výsledků výzkumné metody lze pak i výsledky našeho výzkumu pokládat za relativně stabilní v čase a málo závislé na aktuální skladbě žáků, kteří se nacházeli v popsaném vzorku škol a ročníků. Ačkoliv prezentovaný výzkum neměl povahu longitudinálního sledování žáků, zde uvedená stabilita jeho výsledků zakládá možnost interpretovat výsledky i jako změny, ke kterým dochází u žáků během školní docházky. Lze tedy např. předpokládat, že na zkoumaném vzorku škol by postoj žáků, kteří se $v$ čase dotazování nacházeli v 7. ročníku, byl o rok později shodný jako postoj žáků, kteří se v čase dotazování nacházeli v 8 . ročníku, pokud by se $v$ daném čase neudálo něco mimořádného, co by tento vývoj mohlo radikálněji ovlivnit.

\subsection{Diskuse a limity výsledků výzkumu}

Při interpretaci výsledků uvedeného výzkumu je potřeba mít na zřeteli, že data byla získána na vzorcích žáků, které nelze pokládat za reprezentativní výběry príislušných ročníků jednotlivých typů škol v ČR, a že se nejedná o data longitudinální. I když bylo poukázáno na změnu postojů žáků $\mathrm{k}$ matematice během školní docházky, zůstává nevyřešenou otázkou, do jaké míry jsou tyto postoje ovlivněny školou samotnou a do jaké míry mají na změnu postojů vliv s věkem se měnící zájmy žáků a povaha kurikula matematiky s přirozeně vzrůstající obtižností (čím vyšší ročník, tím vyšší obtižnost). Tuto otázku pomáhá řešit porovnání výsledků našich žáků se žáky jiných zemí v mezinárodních výzkumech TIMSS a PISA. Bohužel se zde mưžeme opřit jen o výsledky ve dvou věkových skupinách. Přesnější pohled na diskutovaný problém by přineslo porovnání vývoje postojů žáků $\mathrm{k}$ matematice našich žáků a žáků ze zemí s obdobným, či naopak jiným uspořádáním kurikula. Takové porovnání však překračuje možnosti této studie, protože si nutně žádá založit podobná porovnání na pevných metodologických základech v podobě srovnatelných výzkumných metod a s kontextovým zohledněním uspořádání a zaměření kurikula po celé sledované období školní docházky.

Jinou možností, jak získat odpověd' na položenou otázku, by bylo experimentální uspořádání s odlišnými metodami (a možná i jinak uspořádaným obsahem) výuky matematiky. Na úrovni druhého stupně základní školy a střední školy se toto možné odlišení v rámci České republiky nenabízí. Zřetelná alternativní a odlišná nabídka 
68 existuje $v$ České republice pro první stupeň ZŠ v podobě učebnic a metodiky Milana Hejného vydaných Nakladatelstvím Fraus. Minimálně s užitím dotazníkových metod se zde nabízí výzkumná otázka, zda se liší postoje žáků $k$ matematice $v 5$. ročníku na základě typu metodiky, kterou se vyučuje. Z našeho výzkumu však vyplývá, že výraznější propad vztahu žáků k matematice se děje během druhého stupně základní školy a dále pak na škole střední. O prvním stupni údaje nemáme.

Dalším omezením prezentovaného výzkumu je výzkumná metoda, která neumožňuje diferencovanější pohled na postoje žáků v porovnání s dotazníkem Hrabala a Pavelkové (2010) či několika významově odlišnými indexy v mezinárodních výzkumech. $V$ zásadě je zde nabídnut pohled skrze dimenzi hodnocení a blízkost pojmu matematika $\mathrm{k}$ dalším pojmům $v$ sémantickém prostoru. Lze jen odhadovat na základě obsahového porovnání užitých škál, že dimenze hodnocení má z hlediska měření postoje nejbliže k oblibě předmětu Hrabala a Pavelkové a vztahu či zájmu o matematiku v indexech mezinárodních výzkumů. Ačkoliv tyto indexy mají nejméně těsný korelační vztah $\mathrm{k}$ aktuálně zjišt’ovaným vzdělávacím výsledkủm, lze předpokládat, že se jedná o indexy, které mají blízko k perspektivní orientaci žáků, a tedy mohou potenciálně ovlivňovat jejich výsledky $v$ matematice $v$ delším časovém horizontu. A nejen to, může se jednat o indexy, resp. složku měřeného postoje $k$ matematice, která má vliv na to, jakým oborům se budou chtít žáci věnovat po ukončení stř̌ední školy, zda oborům vyžadujícím matematiku (př́rodovědným a technickým), nebo oborům, kde se lze matematice spíše vyhnout (oborům humanitním). Ovlivňování těchto preferencí potom může mít nezanedbatelný dopad na vývoj celé naší společnosti. Navíc „pracovně úspěšni“ lidé více oceňují význam matematiky (Walterová et al., 2010). I tato obecná tvrzení však zapadají spiše do okruhu výzkumných otázek než mezi tvrzení podložená dosud shromážděnými a analyzovanými daty.

\section{Závěr}

I přes uvedené limity našeho výzkumu a dosud naznačené a nevyřešené otázky lze formulovat následující souhrnná zjištění, která čerpají z výsledků průměrných hodnot dimenze hodnocení sémantického diferenciálu i z matice vzdáleností pojmů. Oba úhly pohledu vznikají na stejných datech, ale jsou primárně statisticky nezávislé. Proto tam, kde se oba úhly pohledu interpretačně shodují, lze výsledky pokládat za více věrohodné, a právě takové závěry zde vyslovujeme. Navíc tyto závěry nejsou $\checkmark$ rozporu s výsledky z mezinárodních výzkumů PISA a TIMSS a z českých výzkumů Hrabala a Pavelkové $(2010,2012)$.

Vztah našich žáků $\mathrm{k}$ matematice se během školní docházky zhoršuje. Výraznější propad nastává na počátku druhého stupně základní školy. Samotným přechodem na školu střední se tento vztah $v$ průměru nezmění, ale uvedený trend zde dále pokračuje.

$\checkmark$ porovnání s matematikou žáci vnímají cizí jazyk jinak a $v$ zásadě stabilně během celé sledované školní docházky. Vztah k cizímu jazyku je výrazně diferencován mezi žáky podle toho, jaký typ střední školy navštěvují. 
U českého jazyka se zdá, že ho žáci nejhưře vnímají v 6. a 7. ročníku základní školy, ale po té se jejich pohled na český jazyk zlepšuje až po ukončení střední školy. Jistě by stálo za podrobnější zkoumání, do jaké míry má na tyto výsledky vliv povaha kurikula českého jazyka s měnícím se těžištěm mezi gramatikou a literaturou. Střední školou se ve vyslovených závěrech myslí dominantně stř̌ední odborná škola, protože vzorek žáků z tohoto typu školy byl největší.

Vzorek žáků z gymnázií je malý, ale přesto výsledky upozorňují na skutečnosti, které by neměly uniknout pečlivějšímu zkoumání. Zdá se, že žáci na nižším stupni gymnázia mají matematiku a český jazyk ještě méně rádi než jejich vrstevníci na druhém stupni základní školy, přičemž u cizího jazyka je tomu přesně obráceně. Data ani charakter výzkumu nedovolují pouštět se do interpretací. Nabízejí se jen otázky o možné věkově nepřiměřené obsahové zátěži a náročném stylu výuky matematiky a českého jazyka pro většinu žáků, kteři v současné době navštěvují nižší stupně víceletých gymnázií. Tyto otázky necht' se stanou předmětem samostatného výzkumu.

Tato studie by nevznikla nebýt národního projektu Cesta ke kvalitě, v rámci kterého byl vytvořen př́slušný dotazník sémantického diferenciálu a naprogramován portál pro sběr dat. Jmenovitě toto poděkování patří autorovi dotazníku, Radko Pöschlovi, programátorům vedeným Davidem Peškem, adresně Petrovi Hurtíkovi, a garantovi tvorby evaluačních nástrojů, Stanislavu Michkovi, který zajištoval koordinaci mezi tvůrci nástrojů a programátory a organizačně podporoval sběr dat.

\section{Literatura}

Atkinson, R. L. (2003). Psychologie. Praha: Portál.

Hrabal, V., \& Pavelková, I. (2010). Jaký jsem učitel. Praha: Portál.

Chráska, M. (2007). Metody pedagogického výzkumu. Praha: Grada.

Chvál, M. (Ed.). (2012). Školy na cestě ke kvalitě: Systém podpory autoevaluace škol v ČR. Praha: Národní ústav pro vzdělávání, školské poradenské zařízení a zařizení pro dalši vzdělávání pedagogických pracovníků. Dostupné z http://www.nuv.cz/ae/publikace-vytvorene -v-projektu.

Johansone, I., \& Malak, B. (2008). Translation and National Adaptations of the TIMSS 2007. Assessment and Questionnaires. In J. F. Olson, M. O. Martin, \& I. V. S. Mullis (Eds.), TIMSS 2007 Technical Report. MA: TIMSS \& PIRLS International Study Center, Boston College. Dostupné z http://www.timss.org/.

Kerlinger, F. N. (1972). Základy výzkumu chování. Praha: Academia.

Martin, M. O., \& Preuschof, C. (2008). Chapter 12. Creating the TIMSS2007. Background Indices. In J. F. Olson, M. O. Martin, \& I. V. S. Mullis (Eds.), TIMSS 2007 Technical Report. MA: TIMSS \& PIRLS International Study Center, Boston College. Dostupné z http: / / www.timss .org/.

Nakonečný, M. (1995). Lexikon psychologie. Praha: Vodnář.

OECD. (2003). PISA 2003. Technical Report. Dostupné z http://www.oecd.org/edu/school /programmeforinternationalstudentassessmentpisa/35188570.pdf.

Osgood, Ch. E., Suci, G. J., \& Tannenbaum, P. H. (1957). The Measurement of Meaning. Urbana: University of Illinois Press.

Palečková, J., \& Tomášek, V. (2005). Učení pro zítřek. Výsledky výzkumu OECD PISA. Praha: ÚIV. 
70 Pavelková, I., \& Hrabal, V. (2012). Mathematics in Perception of Pupils and Teachers. Orbis Scholae, 6(2), 119-132. Dostupné z http://www.orbisscholae.cz/archiv/2012/2012_2_08 .pdf.

Pöschl, R. (2005). Vnímání významu matematiky a fyziky středoškolskými studenty (Diplomová práce). Praha: MFF. Dostupné z http://kdf.mff.cuni.cz/vyzkum/materialy/vnimani_vyznamu M_a_F.pdf.

Pöschl, R. (2007). Vnímání fyziky středoškolskými studenty - včera, dnes a zítra. Příspěvek prezentovaný na konferenci 50 let didaktiky fyziky, Brno. Dostupné z http://kdf.mff.cuni .cz/vyzkum/NPVII/materialy/Poschl_prispevek_Brno2007.pdf; http://www.ped.muni.cz /wphy/konf/DIDAKTIKA/vystoupeni/Poschl.pdf.

Pöschl, R. (2011). Postoje žáků ke škole. Dotazník pro žáky. Praha: NúOV. Dostupné z http:// www.nuv.cz/file/71/.

Tomášek, V. (Ed.). (2008). Výzkum TIMSS 2007. Obstojí čeští žáci v mezinárodní konkurenci? Praha: ÚIV.

Vašt'atková, J., \& Chvál, M. (2010). K využití sémantického diferenciálu při autoevaluaci školy. Orbis Scholae, 4(1), 111-128. Dostupné z http://www.orbisscholae.cz /archiv/2010/2010_1_07.pdf.

Voňková, H. (2012). Metoda ukotvujících vinět a možnosti využití v pedagogice. Orbis Scholae, 6(1), 27-40. Dostupné z http://www.orbisscholae.cz/archiv/2012/2012_1_02.pdf.

Walterová, E., Černý, K., Greger, D., \& Chvál, M. (2010). Školství - věc (ne) veřejná: Názory veřejnosti na školu a vzdělávání. Praha: Karolinum.

PhDr. Martin Chvál, Ph.D., Ústav výzkumu a rozvoje vzdělávání, Pedagogická fakulta, Univerzita Karlova martin.chval@pedf.cuni.cz 


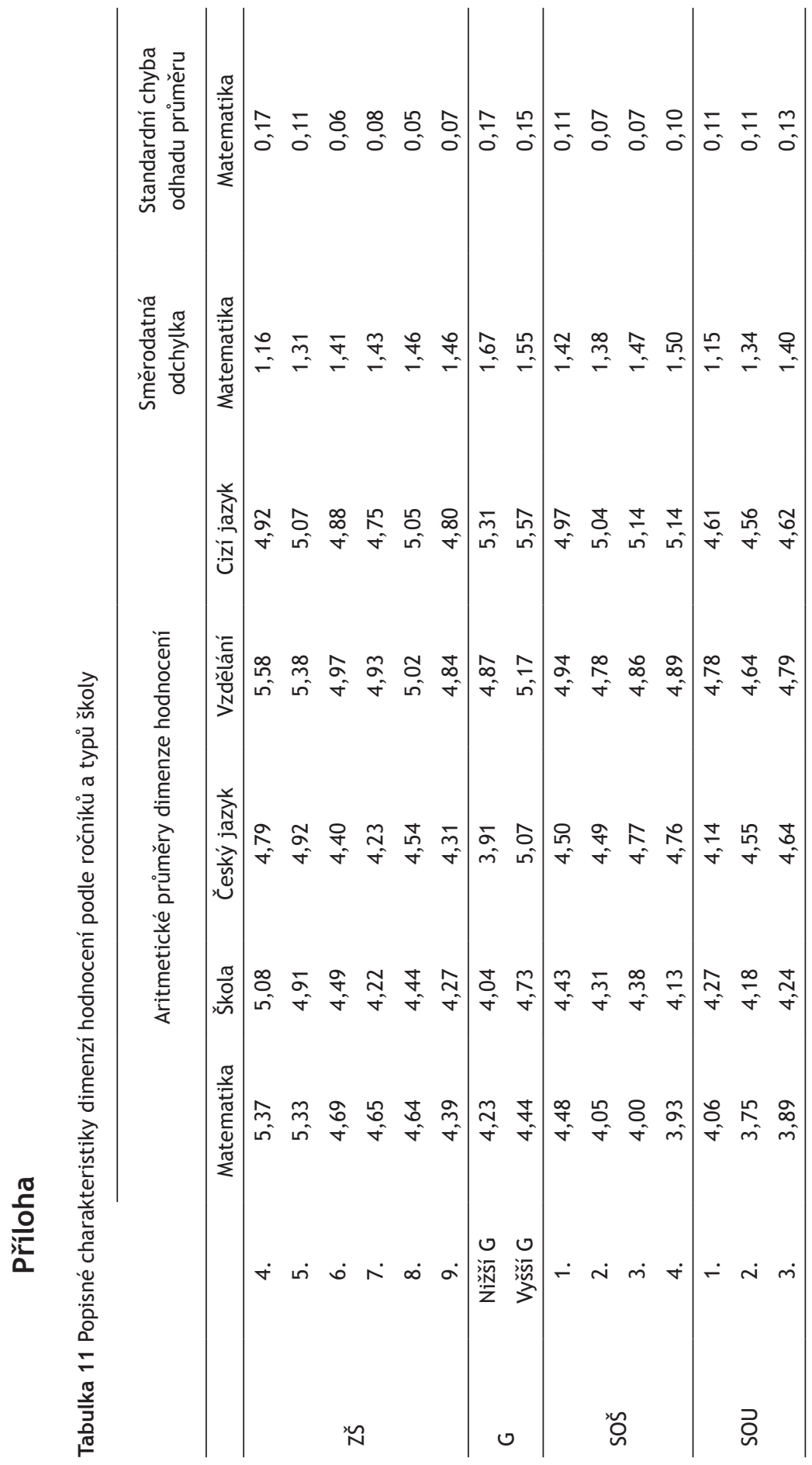

